\title{
EDITORIAL
}

\section{Problems of living meaningfully in psychiatry and philosophy}

\author{
Thaddeus Metz iD \\ Department of Philosophy, University of Pretoria, Pretoria, South Africa.
}

Dan J. Stein's editorial on philosophy and psychiatry notes his recent publication titled Problems of Living. ${ }^{1}$ This a Big Book. I do not particularly mean in terms of length, for the book runs to about 300 pages. I have three other things in mind.

One is that Stein's book addresses some of the most important and difficult questions about the nature of human life and how to live it, among which are: What can we know about human nature and our environment? What is a mind? What is suffering? What is the difference between right and wrong? What makes a life meaningful?

A second is that the book answers these kinds of questions from a bird's eye view, in the first instance considering theoretical answers to them and in the fields of both philosophy and psychiatry (while also addressing some specific, concrete matters). As Stein plausibly suggests in his editorial, combining insights from these two fields is likely not only to enrich our scholarly understanding of psychiatry, but also to help psychiatrists and their patients grapple with practical quandaries.

$A$ third is that in discussing theories of the human condition, the book invokes an amazingly wide array of literature, to the point of citing nearly 2,000 works. (Many are in footnotes, which one need not read to grasp the major points.)

To obtain focus, in the rest of this critical notice I explore Stein's discussion of life's meaning, particularly as it pertains to philosophy, one of this reader's areas of expertise. Stein describes his approach to meaning in life as "integrative," like his approach to all the other major questions he addresses. An integrative position is one that is in between two extremes, taking kernels of truth from each and combining them in a plausible way.

In the context of life's meaning, one integrative approach is to advance a hybrid account of what confers meaning on life, in contrast to a subjective or objective account. A subjective view is that meaning consists of whatever an individual is attracted to, ${ }^{2}$ whereas an objective view is that there is a proper way to live, regardless of the individual's subjective orientation. ${ }^{3} \mathrm{~A}$ hybrid view is that meaningfulness consists of living in the objectively proper way, while also being subjectively attracted to doing so. ${ }^{4}$

Correspondence: Thaddeus Metz, Department of Philosophy, 20-10 Humanities Building, Private Bag X20, University of Pretoria, Hatfield, Pretoria, 0028, South Africa.

E-mail: th.metz@up.ac.za

Submitted Jul 30 2021, accepted Jul 30 2021, Epub Oct 182021.
For another example of an integrative approach to life's meaning, Stein advances pluralism in contrast to both monism and relativism. A monist view is that there is a single kind of life that is meaningful (or at least most meaningful, on which consider Aristotle's prizing of philosophy ${ }^{5}$ ), whereas relativism is the view that any kind of life is meaningful, so long as it is believed to be. A pluralist view is that there are many kinds of life that are meaningful and that cannot be reduced to a single property. ${ }^{6}$

Here is a third illustration of integration. On the one hand, there is the view that we can in principle quantify how much meaning would come from a given action compared to others, say, by adding up the final value of their consequences. ${ }^{7}$ On the other hand, there is the view that it is, if not nonsensical, then at least pointless to think of measuring how much meaning there is in an action (let alone a life), perhaps because meaning is ineffable or incommensurable. ${ }^{8}$ In between, there is the moderate position that, although we cannot specify with cardinal numbers how meaningful an action is, we can know that some actions are more meaningful than others, such that we can make progress. ${ }^{9}$

These examples should give the reader a good idea of Stein's broader project, which this reader finds quite sensible. For all the major topics, he routinely contrasts a more hard-nosed, narrow, scientistic, or objectivist approach (often called "classical") with a softer, lax, interpretive, or subjective approach ("critical"), where his own view is in between. Often "realism" is an apt description of Stein's middle ground. That involves presuming there are objective facts of the matter about meaning and other enquiries, but that there are a variety of ways of apprehending those facts that socially contingent beliefs and practices sometimes facilitate and sometimes frustrate.

For philosophers already sympathetic to an integrative or realist approach, there are details that get glossed over in Problems of Living, but that are naturally of interest. For a first example, suppose one accepts the hybrid approach to what makes a life meaningful. Is being attracted to what one is doing a necessary condition for it to be meaningful, or is it merely a contributory condition? For instance, if a nurse is not drawn to cleaning out patients' bedpans, but does it anyway, does no meaning accrue at all to her life

How to cite this article: Metz T. Problems of living meaningfully in psychiatry and philosophy. Braz J Psychiatry. 2022;44:229-230. http://dx.doi.org/10.1590/1516-4446-2021-0034 
or would there merely be more meaning if she were so drawn? ${ }^{10}$

For a second example, accepting pluralism, the view that there are many sources of meaning in life, can the different sources be grouped in plausible ways? Granted that they cannot be reduced to one basic feature, can they be largely reduced to, say, four major ones? ${ }^{11}$

For a third example, suppose Stein is correct that we can know how to enhance the amount of meaning in our lives, but cannot assign cardinal numbers in the way a consequentialist would seek to do in the manner of costbenefit analysis. Is only an ordinal ranking of meaningfulness available, or is something richer on offer? An ordinal ranking would tell us that it is more meaningful to liberate a country from oppression using non-violent means than it is to feed 1,000 people who would have otherwise suffered from malnutrition, which, in turn, is more meaningful than guiding an old lady across the street. However, it would not tell us anything about whether the extent to which the liberation is more meaningful than the feeding is greater than the extent to which the feeding is more meaningful than the guiding. Is there more to say on that score?

For many of us who have been party to the philosophical debates, the action these days is in addressing how to specify the integrative positions, not so much in defending integration as such relative to the poles between which it lies. However, even philosophers would gain from reading Problems of Living. For one, Stein tends to draw on established integrative approaches in philosophy to articulate and defend more novel ones in psychiatry, which should be of interest to philosophers of mind, neuroscience, psychology, and related fields.
For another, Stein provides big pictures of several controversies that have ranged over many decades and does so all together. It is interesting and illuminating to see the classical/critical/integrative positions comprehensively applied to an array of debates about the nature of mind, knowledge, happiness, morality, meaning, and still others. Stein's Big Book is therefore also revealing as an intellectual history of theorization about the human condition. No small feat.

\section{Disclosure}

The author reports no conflicts of interest.

\section{References}

1 Stein D. Problems of living: perspectives from philosophy, psychiatry and cognitive-affective science. Cambridge: Elsevier; 2021.

2 Taylor R. The meaning of life. In Taylor R. Good and evil. Amherst: Prometheus Books; 2000. p. 319-34.

3 McLellan D. Economic and philosophical manuscripts. In: McLellan D. Karl Marx selected writings. 2nd ed. Oxford: Oxford University Press; 2000. p. 83-123.

4 Wolf S. Meaning in life and why it matters. Princeton: Princeton University Press; 2010.

5 Aristotle. Nicomachean ethics. Irwin T, trans. London: Hackett; 2000.

6 Kekes J. The meaning of life. In: French P, Wettstein H, eds. Midwest studies in philosophy. Vol. 24. Life and death: metaphysics and ethics. Malden: Blackwell Publishers; 2000. p. 17-34.

7 Smuts A. Welfare, meaning, and worth. London: Routledge; 2018.

8 Bennett-Hunter G. Ineffability and religious experience. London: Routledge; 2014.

9 Nozick R. The examined life. New York: Simon \& Schuster; 1989.

10 Metz T. Meaning in life: an analytic study. Oxford: Oxford University Press; 2013. p. 135, 183-84, 196-97.

11 Williams C. Religion and the meaning of life: an existential approach. Cambridge: Cambridge University Press; 2020. p. 56-78. 